\title{
PENYELESAIAN MASALAH 8-QUEEN DENGAN TEKNIK ALGORITMA GENETIK
}

\author{
J. Jamaluddin \\ Universitas Methodist Indonesia \\ jac.satuno@gmail.com
}

\begin{abstract}
Abstrak
8-Queen merupakan suatu bentuk permasalahan kombinasional untuk menempatkan 8 buah bidak ratu (queen) pada papan catur berukuran $8 x 8$. Permasalahan yang terjadi pada 8-Queen diilustrasikan dengan aturan berikut: setiap bidak ratu tidak boleh diletakkan pada saru kolom, satu baris dan satu diagonal yang sama. Untuk menyelesaikan permasalahan ini ada banyak algoritma yang digunakan. Dalam jurnal kali ini saya mencoba untuk menyelesaikan permasalahan 8-Queen ini dengan teknik Algoritma Genetik.
\end{abstract}

Kata Kunci: 8-Queen, Algoritma Genetik, Kromosom, Gen.

\section{Pendahuluan}

N-Queen merupakan salah satu bentuk permainan puzzle yang pertama kali dibentuk pada tahun 1848 oleh seorang pemain catur Max Bezzel. Dari tahun ke tahun, banyak matematikawan termasuk Gauss dan George Canton yang bekerja keras untuk dapat menyelesaikan masalah N-Queen ini. Solusi pertama kali dibentuk oleh Franz Nueck pada tahun1950. Pada tahun 1874 S. Gunter mengusulkan suatu metode dengan menggunakan metode determinan dan J.W.L Gloisher menyaring pendekatan tersebut.

Masalah N-Queen ini dapat diselesaikan dengan menggunakan berbagai algoritma, seperti penelitian yang dilakukan oleh Georffrey De Smet dengan judul "Solving Planning Problem with Drools Solver" yang menjelaskan kemungkinan solusi yang disapat dengan menggunakan algoritma Brute Force $^{[3]}$. Kemudian Sou Yeon Lim dan Ki Jun Soon pada peper penelitian yang berjudul "The Improvement of Convergence Rate in N-Queen Problem Using algoritma $Q$-Learning ${ }^{[4]}$.

Pada peper ini saya mencoba untuk memaparkan proses penyelesaian permasalahan 8-Queen dengan menggunakan teknik algoritma genetik. 


\section{Algoritma Genetik}

Algoritma genetika adalah suatu algoritma pencarian (searching) berdasarkan cara kerja melalui mekanisme seleksi alam dan genetik. Tujuannya untuk menentukan struktur-struktur yang disebut individu berkualitas tinggi di dalam suatu domain yang disebut populasi untuk mendapatkan solusi persoalan ${ }^{[5]}$.

Pada tahun 1975, John Holland memperkenalkan algoritma genetika untuk yang pertama kalinya. Algoritma genetika berbeda dengan algoritma konvensional karena dimulai dari suatu himpunan awal yang disebut populasi. Algoritma genetika menggunakan dua prinsip dasar dalam sistem biologis, yaitu seleksi terhadap spesies yang ada dan peningkatan keanekaragaman (gen dengan operasi genetik) ${ }^{[6]}$.

\subsection{Kromosom dan pola representasi}

Dalam konsep ilmu biologi dikenal adanya istilah sel. Sel merupakan bagian terkecil yang menyusun organisme. Secara umum organisme terdiri dari sel-sel penyusun. Sebuah sel tersusun dari kumpulan beberapa kromosom. Sebuah kromosom tersusun dari beberapa gen. Gen merupakan sekumpulan DNA (Deoxyribo Nucleic Acid). Konsep biologi semacam ini yang diadaptasi pada algoritma genetika. Dalam algoritma genetika, kromosom merupakan alternatif solusi dari sebuah permasalahan. Kromosom dapat disajikan dalam beberapa bentuk sesuai dengan jenis pengkodean yang digunakan ${ }^{[6]}$.

\subsection{Pengkodean kromosom}

Pengkodean merupakan bagian yang penting dalam menyelesaikan suatu permasalahan dengan algoritma genetika. Pengkodean adalah pengkorversian masalah dalam dunia nyata menjadi bentuk yang dapat diolah dengan menggunakan algoritma genetika. Pengkodean yang tepat sangat menentukan berhasil atau tidaknya proses algoritma genetika dalam menyelesaikan sebuah permasalahan. Pengkodean yang tepat juga akan menentukan tingkat efisiensi komputasi yang digunakan ${ }^{[2]}$.

Ada beberapa jenis pengkodean yang dapat digunakan dalam algoritma genetika, diantaranya pengkodean biner (binary encoding) dan pengkodean permutasi (permutation encoding).

\subsection{Skema Pengkodean}

Pengkodean biner merupakan pengkodean yang sering digunakan dan paling sederhana. Sesuai dengan namanya, pada pengkodean biner nilai gen pada sebuah kromosom hanya terdiri dari 0 dan $1^{[6]}$. Contoh kromosom yang menggunakan pengkodean biner ditunjukkan pada gambar 1 .

\begin{tabular}{|c|c|c|c|c|c|c|c|c|c|}
\hline Parameter & \multicolumn{3}{|c|}{$\underbrace{\beta_{1}}$} & \multicolumn{3}{|c|}{$\underbrace{\beta_{2}}$} & \multicolumn{3}{|c|}{$\underbrace{\beta_{3}}$} \\
\hline Binary number & 1 & \begin{tabular}{l|l}
0 & 1 \\
\end{tabular} & 1 & 1 & \begin{tabular}{l|l}
1 & 1 \\
\end{tabular} & 0 & 1 & 1 & 0 \\
\hline & $g_{1}$ & & $g_{4}$ & $g_{5}$ & & $g_{8}$ & $g_{9}$ & & $g_{12}$ \\
\hline Decimal number & & 11 & & & 14 & & & 3 & \\
\hline
\end{tabular}


Gambar 1. Kromosom dengan pengkodean biner

Setetelah skema pengkodean ditentukan, AG diinisialisasi untuk sebuah populasi dengan $\mathrm{N}$ kromosom. Gen-gen yang mengisi masing- masing kromosom dibangkitkan secara random. Masing- masing kromosom akan dikodekan menjadi individu dengan nilai fitness tertentu. Kemudian sebuah populasi baru akan dibentuk dengan menggunakan mekanisme seleksi alamiah, yaitu memilih individu-individu secara proporsional terhadap nilai fitnessnya, dan genetika alamiah, yakni pindah silang (crossover) dan mutasi.

Pada algoritma genetik yang akan digunakan adalah dengan skema pergantian populasi yang disebut generational replacement, artinya, $\mathrm{N}$ kromosom dari suatu generasi digantikan sekaligus oleh $\mathrm{N}$ kromosom baru hasil pindah silang dan mutasi.

\subsection{Nilai Fitness}

Dalam proses evolusi individu yang survive dari proses seleksi alam akan mempunyai kesempatan untuk bereproduksi kembali. Dengan demikian, kemampuan individu untuk dapat beradaptasi dan bertahan hidup untuk selamat sangat penting. Suatu individu dievaluasi berdasarkan suatu fungsi tertentu sebagai ukuran

performansinya. Di dalam evolusi alam, individu yang bernilai fitnes tinggi yang akan bertahan hidup. Sedangkan individu yang bernilai fitness rendah akan mati. Pada masalah optimasi, solusi yang akan dicari adalah memaksimumkan sebuah fungsi likelihood dan meminimumkan least square baik untuk fungsi produksi Cobb-Dauglas maupun fungsi produksi CES.

\subsection{Seleksi}

Pemilihan dua buah kromosom sebagai orang tua, yang akan dipindahsilangkan, biasanya dilakukan secara proporsional sesuai dengan dengan nilai fitness-nya. Suatu metoda seleksi yang umumnya digunakan adalah roulette wheel (roda raoulette). Sesuai dengan namanya, metoda ini menirukan permainan roulette wheel di mana masing-masing kromosom menempati potongan lingkaran pada roda raulette secara proporsional sesuai dengan nilai fitnessnya. Kromosom yang memiliki nilai fitness lebih besar menempati potongan lingkaran yang lebih besar dibandingkan dengan kromosom bernilai fitness rendah.

\begin{tabular}{|c|c|}
\hline Komosom & Nilai Fitness \\
\hline K1 & 1 \\
\hline K2 & 2 \\
\hline K3 & 0,5 \\
\hline K4 & 0,5 \\
\hline Jumlah & 4 \\
\hline
\end{tabular}

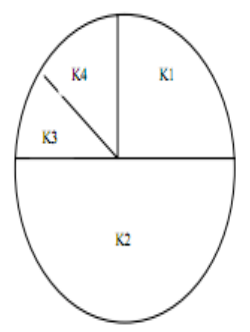

Gambar 2. Penggunaan Metoda Roulette Wheel Selection
Metoda raulette-wheel selection sangat mudah diimplementasikan dalam pemprograman. Pertama, dibuat interval nilai 
kumulatif dari nilai fitness masing-masing kromosom. Sebuah kromosom akan terpilih jika bilangan random yang dibangkitkan berada dalam interval kumulatifnya. Pada Gambar 2 di atas, K1 menempati interval kumulatif $[0 ; 0,25]$, K2 berada dalam interval $(0,25 ; 0,74], \mathrm{K} 3$ dalam interval $(0,75 ; 0,875]$ dan K4 berada dalam interval $(0,875 ; 1]$. Misalkan, jika bilangan random yang dibangkitkan adalah 0,6 maka kromosom K2 terpilih sebagai orang tua. Tetapi jika bilangan random yang dibangkitkan adalah 0,9 maka kromosom K4 yang terpilih.

\subsection{Crossover}

Salah satu komponen yang paling penting dalam algoritma genetik adalah crossover atau pindah silang. Sebuah kromosom yang mengarah pada solusi yang baik dapat diperoleh dari proses memindahsilangkan dua buah kromosom.

\begin{tabular}{|c|c|c|c|c|c|c|c|c|c|c|c|c|}
\hline & \multicolumn{1}{|c|}{$\underbrace{\beta_{2}}_{1}$} & \multicolumn{8}{c|}{$\underbrace{\beta_{3}}_{3}$} \\
\hline Orang tua 1 & 0 & 0 & 1 & 1 & 1 & 1 & 1 & 1 & 1 & 1 & 1 & 1 \\
\hline Orang tua 2 & 1 & 1 & 0 & 0 & 0 & 0 & 0 & 0 & 0 & 0 & 0 & 0 \\
\hline \multicolumn{8}{c|}{$g_{1}$} & $g_{4}$ & $g_{5}$ & \multicolumn{1}{c|}{$g_{8}$} & $g_{9}$ & \multicolumn{1}{c|}{$g_{12}$} \\
\hline Anak 1 & 0 & 0 & 0 & 0 & 0 & 0 & 0 & 0 & 0 & 0 & 0 & 0 \\
\hline Anak 2 & 1 & 1 & 1 & 1 & 1 & 1 & 1 & 1 & 1 & 1 & 1 & 1 \\
\hline
\end{tabular}

Gambar 3. Proses Crossover

Crossover adalah operator Algoritma Genetika yang utama karena beroperasi pada dua kromosom pada suatu waktu dan membentuk offspring dengan mengkombinasikan dua bentuk kromosom. Cara sederhana untuk memperoleh crossover adalah dengan memilih suatu titik yang dipisahkan secara random dan kemudian membentuk offspring dengan cara mengkombinasikan segmen dari satu induk ke sebelah kiri dari titik yang dipisahkan dengan

segmen dari induk yang lain ke sebelah kanan dari titik yang dipisahkan.

Metode ini akan berjalan normal dengan representasi bit string. Performa dari Algoritma Genetika bergantung pada performa dari operator crossover yang digunakan.

\subsection{Mutasi}

Mutasi dapat dilakukan dari semua gen yang ada dengan probabilitas mutasi tertentu. Jika bilangan random yang dibangkitkan kurang dari probabilitas mutasi yang ditentukan maka ubah gen tersebut menjadi nilai kebalikan yang dalam hal ini, binary encoding, 0 diubah 1 , dan 1 diubah 0 . Bila mana probabilitas mutasi adalah ( $1 / 12$ ) maka sebanyak 1 gen akan dimutasi dari kromosom yang terdiri dari 12 gen (bits). Pada algoritma genetika yang sederhana, nilai probabilitas mutasi adalah tetap selama evolusi. Gambar 4 menunjukan proses mutasi yang terjadi pada gen5.

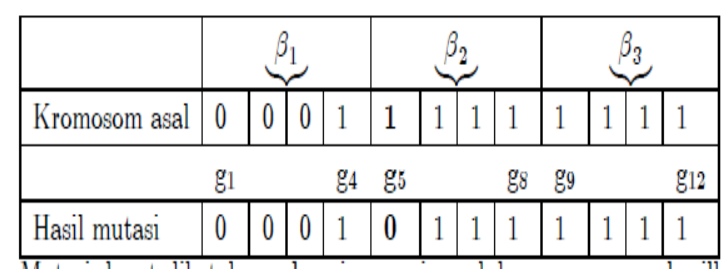

Gambar 4. Contoh Mutasi pada Gen5

MAJALAH ILMIAH METHODA Volume 2 Nomor 2, Mei-Agustus 2012 : 14-20

Halaman 17 


\subsection{Elitisme}

Proses seleksi dilakukan secara random sehingga tidak ada jaminan bahwa suatu indvidu yang bernilai fitness tertinggi akan selalu terpilih. Walaupun individu bernilai fitness tertinggi terpilih, mungkin saja individu tersebut akan rusak (nilai fitnessnya menurun) karena proses pindah silang. Oleh karena itu, untuk menjaga agar individu bernilai fitness tertinggi tersebut tidak hilang selama evolusi, maka perlu dibuat satu atau beberapa kopinya. Prosedure ini dikenal sebagai elitisme.

\section{Langkah-langkah Algoritma Genetika}

Algoritma genetika dimulai dengan membuat himpunan solusi (kromosom) yang disebut dengan populasi. Populasi mula-mula dibuat secara acak. Selanjutnya populasi yang sudah terbentuk akan digunakan untuk membentuk populasi yang baru dengan harapan populasi yang baru lebih baik dari populasi sebelumnya. Solusi-solusi yang ada dalam populasi kemudian dipilih untuk membentuk solusi baru (offspring), yang dipilih berdasarkan nilai fitness-nya. Proses ini diulang sampai kondisi yang diinginkan. Berikut ini adalah urutan proses algoritma genetika

1. Inisialisasi populasi, membuat populasi secara acak

2. Evaluasi nilai fitness.

3. Membuat populasi baru dengan cara seleksi, crossover dan mutasi.
4. Update generasi, ganti populasi yang lama dengan populasi baru.

5. Cek kondisi berhenti, apabila belum terpenuhi maka kembali ke proses 2 .

\section{Perancangan Algoritma Genetik 8- Queen}

8-Queen merupakan suatu bentuk permasalahan kombinasional untuk menempatkan 8 buah bidak ratu (queen) pada papan catur berukuran $8 \times 8$. Permasalahan yang terjadi pada 8-Queen diilustrasikan dengan aturan berikut: setiap bidak ratu tidak boleh diletakkan pada saru kolom, satu baris dan satu diagonal yang sama.

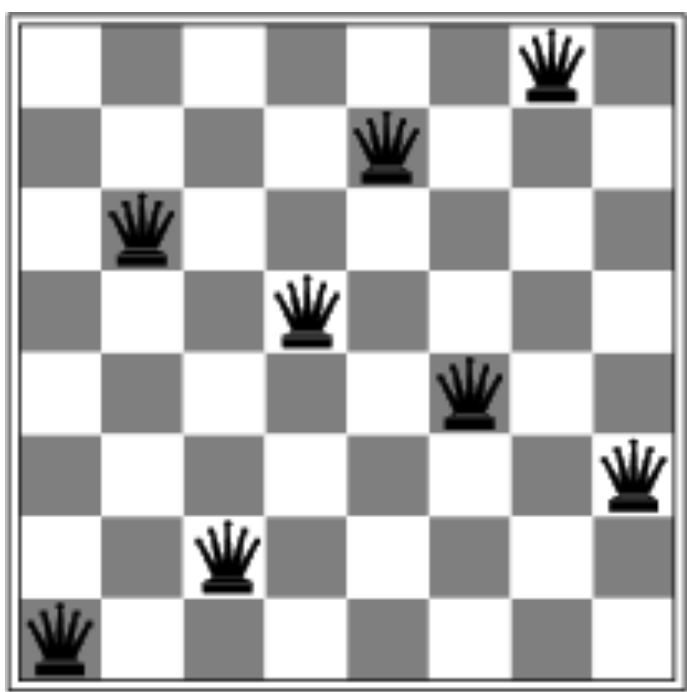

Gambar 5. Ilustrasi sebuah Posisi 8-Queen

Posisi 8-Queen diatas jika ditranformasik ke dalam kromoson akan dipeoleh tabel kromosom berikut: 


\begin{tabular}{|l|l|}
\hline Gen 1 & 1 \\
\hline Gen 2 & 6 \\
\hline Gen 3 & 2 \\
\hline Gen 4 & 5 \\
\hline Gen 5 & 7 \\
\hline Gen 6 & 4 \\
\hline Gen 7 & 8 \\
\hline Gen 8 & 3 \\
\hline
\end{tabular}

Gambar 6. Tabel Kromosom 8-Queen pada Ilustrasi

Proses penghitungan nilai fitness untuk kromosom pada 8-Queen dilihat dari seberapa sering terjadi perpotongan baik secara vertical, horizontal ataupun diagonal. Kemudian dari nilai fitness tersebut kita dapat mengambil 2 individu pada tahap seleksi sebagai orang tua (parents).

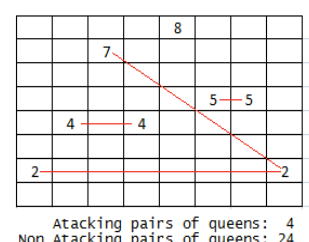

Acking pairs of queens: 24

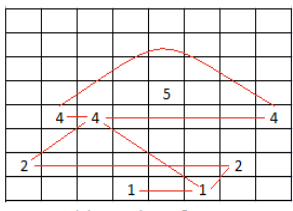

Atacking pairs of queens: 8
Atacking pairs of queens: 20
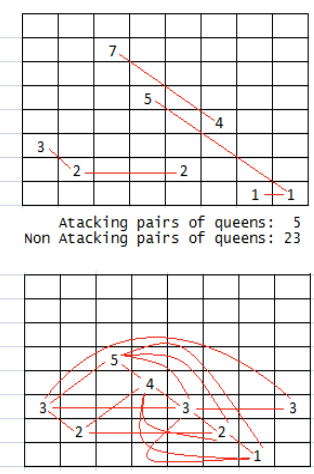

Atacking pairs of queens: 17
Atacking pairs of queens: 11
Gambar 7. Penentuan Nilai Fitness pada 8 -

Queen

Dari parents tersebut kita akan melakukan crossover terhadap gen-gen pada individu yang di kawinkan. Pada proses perkawinan (crossover) tersebut dimungkinkan terjadinya mutasi pada salah satu atau lebig gen yang sifatnya acak. Sehingga prosesnya dapat diilustrasikan pada Gambar 8 berikut:

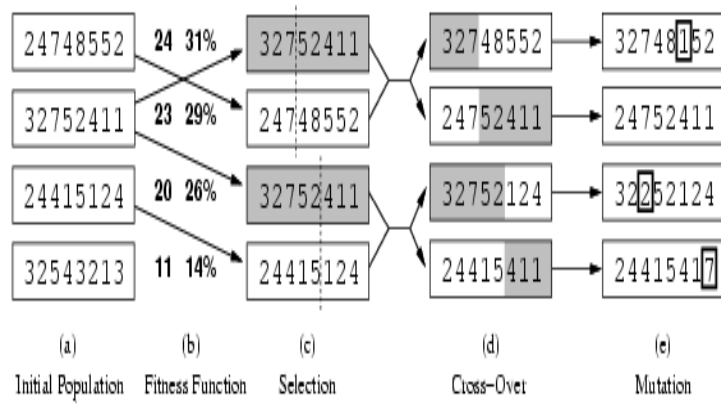

Gambar 8. Proses Algoritma Genetik pada 8-

Queen

\section{Kesimpulan dan Saran}

Pada jurnal kali ini, saya hanya melakukan perancangan terhadap proses Algoritma Genetik terhadap permasalahan 8Queen. Untuk selanjutnya mudah-mudahan rancangan ini dapat diimplementasikan dalam bentuk sebuah aplikasi sehingga dapat diketahui berapa generasi proses terjadi untuk mendapatkan individu dengan nilai fitness yang diinginkan.

\section{Daftar Pustaka}

[1] Adrifina, A., dkk. 2008. Penyelesaian Masalah N-Queen dengan Teknik Backtracking. Proceeding Seminar Ilmiah Nasional dan Sistem Intelijen (KOMMIT 2008), Depok. 
[2] Situmorang, Zakarias., Penyusunan Teka - Teki Silang dengan Algoritma Genetika.

[3] Geoffrey, S., 2008, Solving Planning Problems with Drools Solver.

http://anonsvn.labs.jboss.com

[4] Soo-Yeon Lim., 2008, The Improvement of Convergence Rate in N-Queen Problem Using Reinforcement Learning. http://www.icis.ntu.edu.sg

[5] Kusumadewi, S, 2003, Artificial Intelligence. Yogyakarta: Graha Ilmu.

[6] Desiani, A. \& Arhami, M, 2006, Konsep Kecerdasan Buatan. Yogyakarta: Andi.

[7] Heaton, J., Understanding Genetic Algorithm.

www.jeffheaton.com/ai/javaneural

[8] Kuswadi, S., 2007, Kendali Cerdas: Teori dan Aplikasi Praktisnya. Yogyakarta: Andi. 